\title{
Investigation into Multicultural Readiness of Maritime Students: A Maritime English Lecturer's View
}

\author{
Adelija Čulić-Viskota
}

Maritime affairs imply multinational/-cultural/-lingual work environments, and maritime students' relative attitude should be investigated and the awareness raised. A research was undertaken with the 1st-year students of the Faculty of Maritime Studies (FMS) in Split, aiming at getting to know their cultural profile and their views of otherness. This is an essential starting point for the education of tolerant and knowledgeable seafarers, able to foresee possible problems arising in intercultural contacts, e.g. of a ship's crew, and to deal with them if they should arise. Even before the introduction of multicultural elements into the university education of seafarers, some shipping companies had recognized the problem in an early stage and started undertaking individual initiatives to build respect and tolerance among crewmembers on board their ships originating from different national and cultural backgrounds. Since new nationalities are constantly entering the shipping industry scene, maritime students should be taught to: firstly, recognize the otherness and respect the different shapes it takes, and secondly, recognize the importance of the English language, not only as the occupational language in shipping and means

\section{KEY WORDS}

$\sim$ Multicultural

$\sim$ Multilingual

$\sim$ Occupational language

$\sim$ ESP

$\sim$ Maritime English of their professional communication, but also as their social life mediator in their working and living environment. A possible approach to this topic is proposed by an instructor of English for specific purposes in the maritime domain. It is through language that various attitudes presented by different nationalities in a variety of settings can best be illustrated.

\section{INTRODUCTION}

Maritime affairs have always, of necessity, been an intersection of different nationalities and cultures due to the very nature of this business. Shipping has always meant international affairs, in the sense that trade, warship or explorations long ago forced seafarers to leave the familiar homeland waters and venture on journeys to distant foreign lands. Ever since, the need has been felt to armour seafarers with the knowledge of science to enable them to cope with the forces of nature and the relative response of their vessels, but also to take into consideration the human element, both on board ship and on shore. The ruling position of the English language in shipping has certainly facilitated maritime operations, but if proper care is not taken of crewmembers' cultural backgrounds, the gap among them can be widened instead of bridged despite the common occupational language. Therefore, a number of studies have been conducted dealing with shipping as a multicultural setting, and the most represented crewmember nationalities. This paper aims at presenting the importance of raising frequently maritime students' awareness of their future working environment, which is particularly important for the students originating from environments with low multicultural sensitivity, due to living in almost mono-cultural countries with an extremely low percentage of foreign citizens. It is, therefore, of the utmost importance to first measure the multicultural sensitivity of the 
students enrolling for maritime studies, so as to clearly see what exactly the tasks of Maritime English lecturers should be. Due to the nature of their field of humanities and branch of linguistics, they should certainly take one of the leading roles and join in with their students to produce a wider range of materials intended for facilitating their students' passage to real-life situations in multicultural environments.

\section{SHIPPING AS A TRADITIONALLY TRANSITIVE ACTIVITY IN MULTICULTURAL SETTINGS, AND THE NEED FOR A COMMON WORKING LANGUAGE}

Since the early settling of the Germanic tribes on the shores of the British Isles, the spoken language has begun its development to become the global modern English language as we know it today. Already the Old English of Beowulf represents a variety of literal terms for a ship, while following the poetic diction technique called kenning allusive compounds have been found, e.g. the term meaning literally whale-road, actually denoting the sea, while wave-traverser/rider was used to denote the ship. The mastery of the seas and ships was of greatest importance for the newcomers' incursions. Thus, the English words ship and boat are held to originate from this period. The Frisians, from what is now northern Holland and north-western Germany, were also among the invaders, and it is believed that the English words sea, boat, storm, rain, snow, freeze, frost, mist, all important or related to shipping, originate mainly from Old High German, Old Norse and Frisian'. Thus, ships and shipping already in those early days connected people of different backgrounds, their intercultural contacts resulting in changes, e.g. linguistic. Only much later on, during the times of great explorations will there be different nationalities mentioned as manning ships, such as the case of the Portuguese Magellan's Spanish expedition with vessels manned by culturally diverse crew. ${ }^{2}$ Other famous names from the seafaring history were well-known as internationalists, e.g. Thor Heyerdahl, Roald Amundsen ${ }^{3}$.

However, British colonialism was definitely a major cause of propagation of the English language across the oceans from the British Isles around the globe, where it has established itself as an essential means of global communication in different human activities and businesses, maritime affairs included. With the times of colonisation of new territories by the leading European nations, there appeared a spread of the English language into colonialised areas, but also onto the activities involved in colonialisation itself, shipping certainly being part of it. According to Samuel

1. According to Merriam Webster's online dictionary, available at: https://Www. merriam-webster.com/dictionary (accessed February 15, 2017)

2. For more details, see Čulić-Viskota, A., 2015

3. Amundsen's 1897-99 Antarctic exploration featured a vessel manned with a Belgian master and crewmembers of Norwegian, Polish, Romanian, American, French, and Swedish origins.
Osborne, relating results of a survey on the British colonial past in The Independent ${ }^{4}$ early in 2016, "At its height in 1922, the British empire governed a fifth of the world's population and a quarter of the world's total land area." The British were the leading colonial nation of the time and the English language influenced a number of minor languages, which resulted in a number of pidgins and creoles. Further developments in shipbuilding and navigation of the period facilitated and fostered the contacts. Still, the situation has changed over time. English has certainly become the global language without any real contenders, but the circumstances in shipping have in the meantime changed. The British are no longer the leading maritime nation they used to be, while the English language has seen the appearance of Maritime English as an independent jargon spoken and written by seafarers of origins different from the British. According to Alfiani (2010: iv), "The declining number of seafarers from major ship-owner countries (EU, USA, Japan, etc.) has been one of the reasons which pushed the ship owners and employers to man their ships with crews from various nationalities." Seafaring is not so attractive any more to the citizens of developed countries, but it continues to attract citizens of developing countries. Therefore, the need has arisen for a common occupational language that would ensure the safety of navigation.

\subsection{Multicultural Awareness of Shipping Companies - Early Stage}

A modern ship may be considered as the meeting point of representatives of different cultures gathered into a working team aiming at making profit for themselves and their employers. In this sense, a culturally diverse team has to live and work in a restricted space - their vessel, which certainly makes the scene more complicated. As it has already been stated, " $A$ fish only discovers its need for water when it is no longer in it. Our own culture is like water to a fish. It sustains us. We live and breathe through it." ${ }^{5}$ This simply means that, when not supported by one's own culture, a person feels like a fish out of water, i.e. not relaxed, insecure, deficient, frustrated. Thus, if not provided with multicultural awareness and readiness to understand and adapt to foreign cultures, one can hardly feel ready to work and accomplish the required tasks. On the other hand, there is a Hindu proverb expressing an apparently controversial thought: "The three great mysteries: air to a bird, water to a fish, and human kind to itself." On a second thought though, it means exactly what Fons Trompenaars and Hampden-Turner stated, because we usually tend to take our environment for granted, seldom being aware of its importance to our functioning and self-realisation.

4. "5 of the worst atrocities carried out by the British Empire", an article authored by Samuel Osborne, appeared on the Independent of January 19, 2016

5. Fons Trompenaars and Charles Hampden-Turner. Riding the Waves of Culture. New York: McGraw-Hill Publishing, 1997 
After all, in old Greek there was a phrase introduced by Aristotle

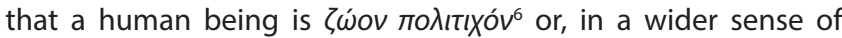
the term, a social animal, i.e. a living being predisposed to live in a social group. Despite different interpretations of moגıтıкóv in this Aristotle's phrase, it could easily be understood as the characteristic of the human kind to cooperate within a group in a common enterprise, or to communicate within a community of a kind.

In the early 1990s modern shipping companies have realised the importance of the community of a ship's crew, as well as that of communication in both its linguistic and social aspects. The Japanese NYK shipping company management was among the first to make efforts to raise the level of cultural awareness or cultural literacy essential to intercultural communication. Having conducted a research among all their employees originating from different countries and cultures, they compiled Guidelines on Understanding Intercultural Relationship - a circular sent to ship masters to be provided in the messrooms and conspicuous places on board. In Part One of the Guidelines, intercultural relations are explained. First, it is stated as a fact that within a ship's crew there are mutual influences at work - people recognise different ways of coping with problems. No culture is common to all people cultural differences are natural and inevitable. Crewmembers are instructed to learn from representatives of different cultures and to seek similarities as a way of bridging the differences. Also, crewmembers are warned of the danger of falling into the trap of generalisations and stereotypes. They are instructed to be "careful when expressing beliefs, slow in communicating them and to avoid unknown or culture-specific words / phrases". Part Two of the Guidelines, titled "Practice Cultural Sensitivity", is introduced by the idea that each person is unique and there is a need for: a) respect of "other" (= different) attitudes and customs, and b) consideration of religion and culture as part of one's personality. A conclusion is drawn that differences should be expected and consideration and respect should guide a person's behaviour. The rest of the Guidelines is dedicated to individual cultures whose representatives man NYK vessels. Each chapter is divided into Dos, Don'ts and Things to Remember When with ... Among the concepts presented is Mianxi in the Chinese culture, which is associated with the concept of face in the Western cultures,

6. According to some encyclopaedic interpretations (http://www.enciklopedija. hr/natuknica.aspx?id=67397 and http://www.encyclopedia.com/history/ dictionaries-thesauruses-pictures-and-press-releases/media-history) Aristotle's

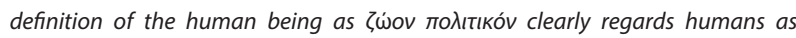
properly belonging to a polis or community, but also indicates that humans are distinguished by communication since there can be no conception of a community without communication, and vice versa, as the Latin etymologies suggest.

7. Mianxi (pronounced mianzi in Mandarin Chinese), as a trait of Chinese culture, was first mentioned by an American missionary to China in the 19th ct. His name was Arthur Smith, and he spent 54 years in China. In the resulting book called "Chinese Characteristics", he pointed out that this was the key concept to understanding Chinese personality. or obraz in the Slavic ones, e.g. Croatian, Serbian, Bulgarian as exemplified by Stojanovich (1994: 48-9). All the examples refer to politeness in communication. It was introduced into the English linguistics by Goffman in 1959, later dealt with by Brown \& Levinson in $1987^{9}$. The aim of developing such strategies of polite communication is to enable ourselves as speakers to save the face of the interlocutor and our own. It is important to avoid face threatening acts and to use positive politeness instead. The Guidelines have been revisited for the purpose of this paper after a 10-year period ${ }^{10}$. As more nations have emerged on the shipping scene in the meantime, the Guidelines have been extended with the characteristics of the Filipinos, Indians, Croats, Romanians, followed by "General Perspectives on the Culture of Nations in Transitions / South East Europe: (Albania, BosniaHerzegovina, Bulgaria, Croatia, FYR Macedonia, Kosovo, Moldova, including Romania, Serbia-Montenegro, Slovenia)". There are practical tips about each culture in the descriptive introduction. Still, the main point seems to be misunderstood, as can be seen from the extract below:

"It is hoped that through this guideline readers will have the awareness in breaking the barriers, deterring misconception and misjudgement against certain cultures that may hinder a productive relationship on board a ship; and for a greater number of our people to feel greater satisfaction and enjoyment because of an enhanced good working relationship in any ship. Please post this circular to the mess halls and other conspicuous areas on board so that it will serve its purpose."

While it is certainly a good idea to post memos in visible places to be caught by the viewer's photographic memory, the expectation that it will substantially contribute to resolving possible breakdowns in intercultural communications is far from realistic. Raising awareness of problems is just the first step towards a less critical approach to other cultures, while only a much more comprehensive training including practical exercises could be expected to result in real changes in an individual's attitude.

\subsection{Multiculturalism as Represented in the Maritime University Studies at FMS}

For the purpose of this paper, an investigation into the university courses incorporating multiculturalist topics in the

8. Croatian obraz, according to the Croatian Language Portal (Hrvatski jezični portal-HJP): conn. honour, honesty, pride. The item is followed by 10 different phrases, all having connotative meanings. (available at: http://hjp.znanje.hr/ index.php?show=search_by_id\&id=eFtmUBE\%3D)

9. More about the concept of face and the communicative category of politeness in Culić-Viskota A.(2002)

10. Guidelines for intercultural relations, issued by NYK shipping company, were first consulted in 2007 and mentioned in a conference paper presented at 2007 International Maritime English Conference in Rotterdam, Netherlands. 
curricula designed and implemented at the Faculty of Maritime Studies of the University of Split, has been undertaken.

The results have shown that multiculturalist topics are represented in the Nautical and Marine Engineering departments, with only one relative core course, Psycho-sociology, at the undergraduate level for nautical students, and Work Organisation and Management on Board for marine engineering students. The students of Marine Electrical Engineering and Information Technologies are offered the elective course Work Organisation and Management on Board in the $3^{\text {rd }}$ semester, and the core Safety at sea in the $6^{\text {th }}$ semester. Maritime management students have two core courses in the $2^{\text {nd }}$ semester, Management in Shipping and Ports, and $3^{\text {rd }}$ semester, Communicology, with an additional possibility of elective Socio-psychology in the $6^{\text {th }}$ semester, as they are obviously expected to deal with people originating from different cultures, whether they work on board or on shore. The best educated students in this respect should result from Marine Yacht and Marina Management studies, as they are offered the core Communicology and elective Socio-psychology in the undergraduate, and two compulsory courses, Human Resource Management and Psycho-sociology, related to multiculturalist topics in the graduate studies.

In the compulsory course in Psycho-sociology, a lecture is dedicated to the acceptance / inclusion of others: identity and multiculturalism on board. Still, it is only a 1.5-hour lecture, without discussion or exercises to follow. This can only give students an idea of the topic without a more serious possibility of examining or deepening it. In the elective course Work organisation and management on board for the students of Marine engineering, one of the topics dealt with is Management in the conditions of cultural differences. Students of Marine electrical engineering and information technologies, except for the possibility of the elective course in Work organisation and management on board, have no multiculturalist topics included in any of the core courses, although the course in Safety at sea (45 hours of lectures and 15 hours of exercises) could certainly provide students with more than technical knowledge about the behaviour in emergencies. A number of International Maritime Organization Casualty Reports point out poor communications between different cultures as factors leading to accidents. More lecture themes related to multiculturalism can be found in the course on Communicology, and these are referred to as Intercultural and non-verbal communication, as well as Organisational communication. Finally, the course in Human resource management incorporates ideas about neuro-linguistic programming, which can also be related to multiculturalism, but no other topics within this course have been detected to relate to it.

\subsection{Multiculturalism as Part of Maritime English Courses, and the Related Teaching Materials}

The idea of multiculturalism should, more than in any other courses, be part of Maritime English courses at maritime universities. An investigation has been conducted into some teaching materials for Maritime English courses at this point, with the objective to find out how much multiculturalism there is. The results are not encouraging. For example, ships' crews in the teaching materials considered mainly consist of crewmembers of European origin: English, Scottish, German, Finnish, Polish or Latvian. No other nationalities are mentioned which currently represent a greater part of ships' crews. The materials should therefore be reviewed periodically, and alterations to suit current practices should be made if the materials are to remain in use over a lengthy period of time due to their being high-quality teaching materials from other aspects. Secondly, students' level of the English language knowledge at enrolling in university studies has been observed to be increasing rapidly due to their exposure to English through written and spoken communication. Therefore, due to the existence of modern e-learning Maritime English teaching materials such as those resulting from the MarEng Project as well as the already iconic IMLP, the students at maritime universities can very well acquire the basic terminology through independent e-learning, while the Maritime English lecturer should assist them, among other things, in the acquisition of intercultural communication skills. The terminological aspect of Maritime English is a kind of knowledge that is easily obtainable, understandable and easy to remember. Most of the time a Maritime English lecturer has for the terminology-related part of the syllabus should be dedicated to the disambiguation of terms. The topics like multi-/intercultural ones are currently those which should be more closely and extensively dealt with. More time should be dedicated to the topics on which safety provided by appropriate communication is based. Communication can be expected to be appropriate only when the participants are able to tolerate, understand, and accept one another, and this goal cannot be reached by insisting on the operational language only, but on the language in use, i.e. what the participants in a communication act can do with the language, which again is highly dependent on the cultures from which they originate. Therefore, the Maritime English lecturer should certainly be an English lecturer, but also an intercultural broker ${ }^{11}$, who will help to educate culturally literate ${ }^{12}$ seafarers.

11. The term is used and explained extensively by Bocanegra-Valle, A. (2015) Intercultural Learners, Intercultural Brokers and ESP Classrooms: The Case of a Shipping Business Course

12. The term cultural literacy was coined by E.D. Hirsch (1987), and reappeared in Hirsch, Kett, \& Trefil's (2002). 


\section{CULTURAL PROFILE OF THE 1ST-SEMESTER STUDENTS AT FMS, AND THEIR VIEWS OF OTHERNESS}

In order to be able to incorporate multiculturalism topics into Maritime English courses for the students at the Faculty of Maritime Studies in Split, a need was felt to discover their worldviews and attitudes towards otherness and inclusion, and to specify what the points of departure and destination should be, i.e. how long our voyage to understand and accept otherness and its inclusion would be, and what the teaching material should concentrate on.

\subsection{Research Methodology: Use of Appropriate Multiculturalism Questionnaire}

First, the decision had to be made on an appropriate questionnaire to be used for the purpose. There are already numerous questionnaires available worldwide, which had been devised for different purposes by different specialists in various fields, mostly psychologists. Thus, the decision was reached to use the Multiculturality Experience Questionnaire devised by Narvaez (2009) ${ }^{13}$. Still, it was devised for different target audiences and was not entirely appropriate for the Croatian students of maritime studies due to its containing a number of items not relevant for this purpose, e.g. those referring to the state of affairs specific for the USA, including the country-specific minority groups. So, the Narvaez Multiculturality Experience Questionnaire (MEQ) was adapted with the permission obtained from the author by retaining the first 15 items and leaving out the remaining 2 strictly USA-specific ones. The original scales by which the students' answers were analysed have also been retained.

The investigation was carried out with the $1^{\text {st }}$-semester students in order to better familiarise the Maritime English lecturers with the kind of prevailing student mindset, i.e. their mental attitudes or predispositions that predetermine their responses to and interpretations of persons and situations. The questionnaire had to be inclusive enough to allow drawing conclusions but, at the same time, of appropriate complexity and length that would not discourage the $1^{\text {st }}$-semester students from participating in the research.

According to Narvaez's idea, even in the adapted questionnaire, i.e. without the two additional items, there are two different subscales:

1. The Multicultural Experience subscale to which the items numbered $1,3-5,7,12,13,14$, and 15 refer;

13. Darcia Narvaez, Ph.D., University of Notre Dame, IN., USA and her collaborators devised the questionnaire in 2009. With permission grant, the questionnaire was adapted for the purposes of this study.
2. The Multicultural Desire subscale to which the items numbered 2, 6, 8, 9, 10, and 11 refer.

The Multicultural Experience subscale helps in getting acquainted with the students' current experiential assets, while the refers to the person's willingness or desire to increase their multicultural experiences and may be considered as an indicator of their open-mindedness.

\subsection{Results and Discussion}

The total number of 225 students from the 5 departments of the FMS participated in the survey by anonymously answering and filling in a 15-item-questionnaire.

The following is the analysis of each of the 15 items of the questionnaire, as answered by the 225 students.

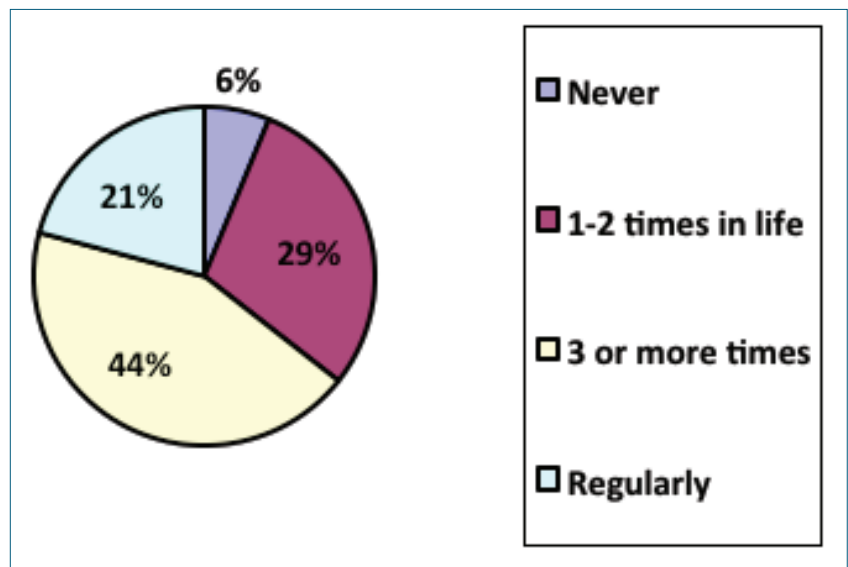

Figure 1.

Results of answers to Item 1: How often do you travel out of your country?

Figure 1 shows that $65 \%$ of the students, who travel regularly or have travelled three or more times out of their own country, can be considered appropriate for the job of a seafarer, who will probably spend most of their working time abroad, in different countries and foreign cultures. However, $6 \%$ of the students have never been out of their own country by the age of 18 . This can be an indicator of their possibly not having a clear idea of what is expected of them in their future job.

Figure 2 shows that $97 \%$ of the students want to travel outside of their country, which is an essential attitude for their future job. However, the remaining $3 \%$ of the students are not at all keen on leaving their country for their job, which is certainly not an attitude in favour of the seafaring profession. 


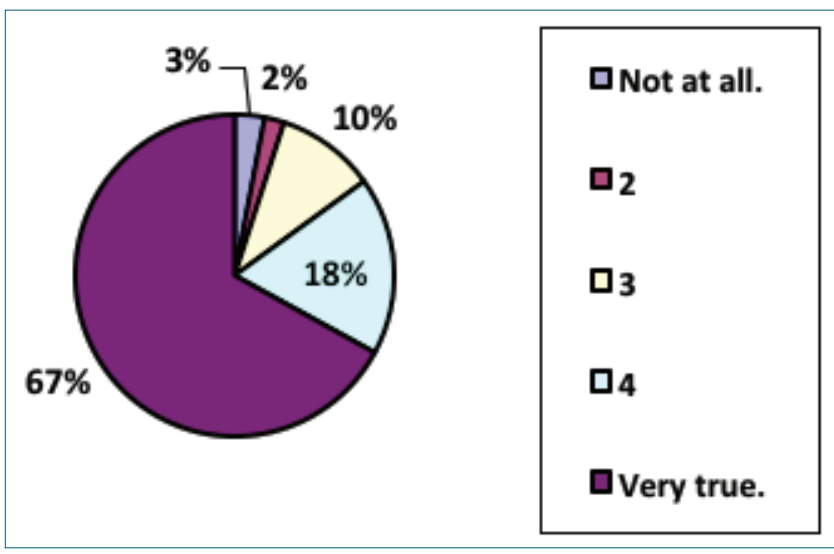

Figure 2.

Results of answers to Item 2: I want to travel outside of my country.

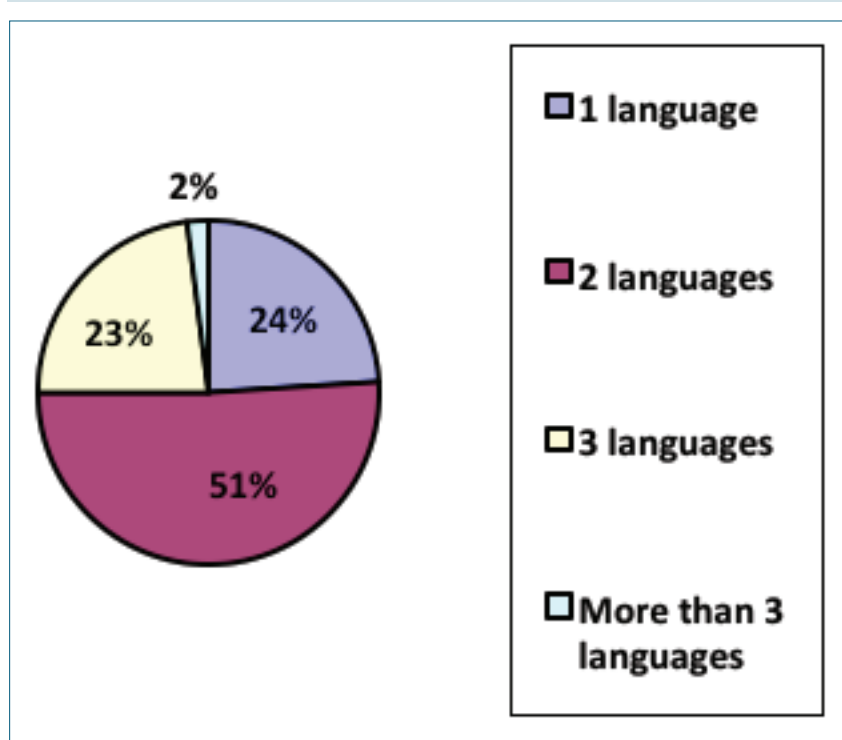

Figure 3.

Results of answers to Item 3: How many languages do you speak well?

Figure 3 shows an encouraging result of the students knowledge of languages. Although English is the operational or vocational language in maritime affairs, there are different situations in onboard activities, e.g. during pilotage, when the activities are facilitated by the knowledge of the local language. ${ }^{14}$ Thus, $76 \%$ of the students speak well at least two or more languages. However, the percentage of students who have stated that they speak well only one language (i.e. mother tongue), is considered too high.

14. For more about Master-Pilot-Tug communication characteristics and problems, see: Čulić-Viskota, A. (2014); (2015).

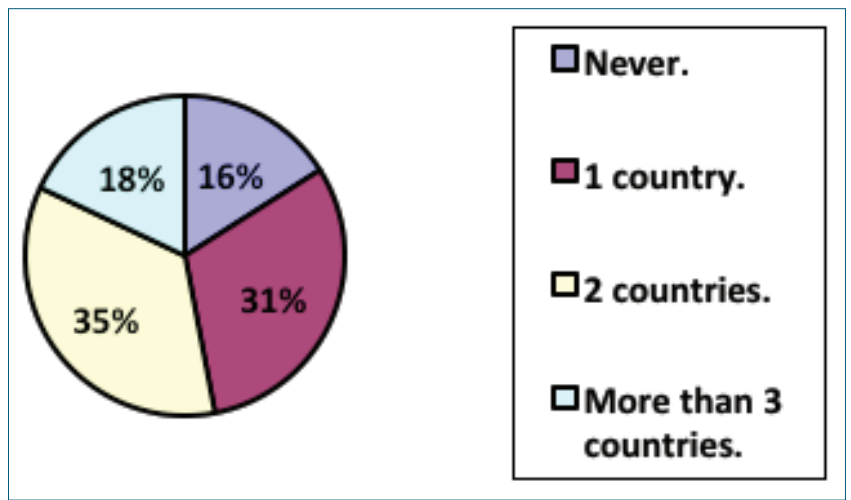

Figure 4.

Results of answers to Item 4: I correspond currently with people from other countries.

According to Figure $84 \%$ of the students correspond with people from other countries, which can develop not only their knowledge of the language used for correspondence, but also of the elements of knowledge of other cultures. This fact can be used in the classroom work and these students can be given the opportunity to present the elements of their communication that they consider of possible interest to their colleagues, and the latter can indirectly get in contact with different cultures in this way.

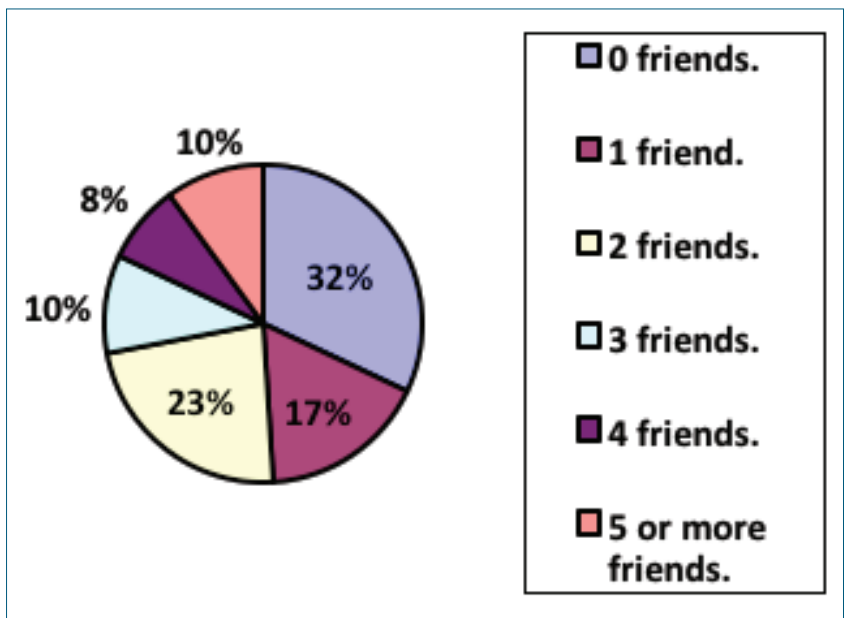

Figure 5.

Results of answers to Item 5: I have friends from cultural / racial / ethnic backgrounds different from my own.

Figure 5 shows that $68 \%$ of the students have at least one or more friends with cultural / racial / ethnic backgrounds different from their own, and it is an encouraging fact as regards the development of their readiness to accept otherness in different forms it may take, or at least an initial predisposition 
to the development and growth in this regard. The ship's crew is based on hierarchy, but they have to live as a family, in a limited space and with respect for one another.

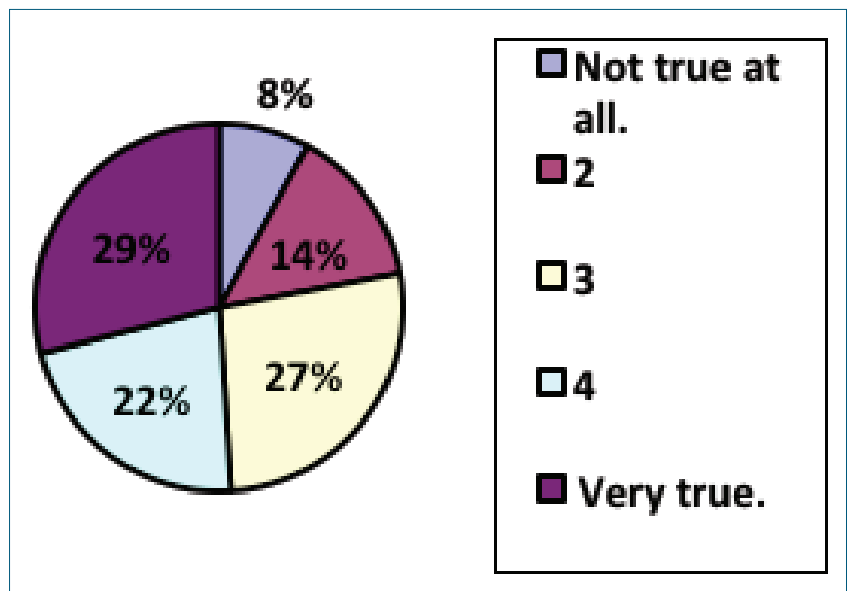

Figure 6.

Results of answers to Item 6: I want to have friends from different cultural/racial/ethnic backgrounds.

Figure 6 shows that $92 \%$ of the students want to establish friendly relations to persons of different cultural / racial / ethnical backgrounds. This indicates their open-mindedness essential in their future jobs. However, $8 \%$ of the students expressed overt disinterest or reluctance to do so, which makes them a group of particular interest for the lecturer, whose aim should be to try to make them contemplate on the nature of friendship and possibilities of making friends with persons of cultural or other backgrounds different from their own.

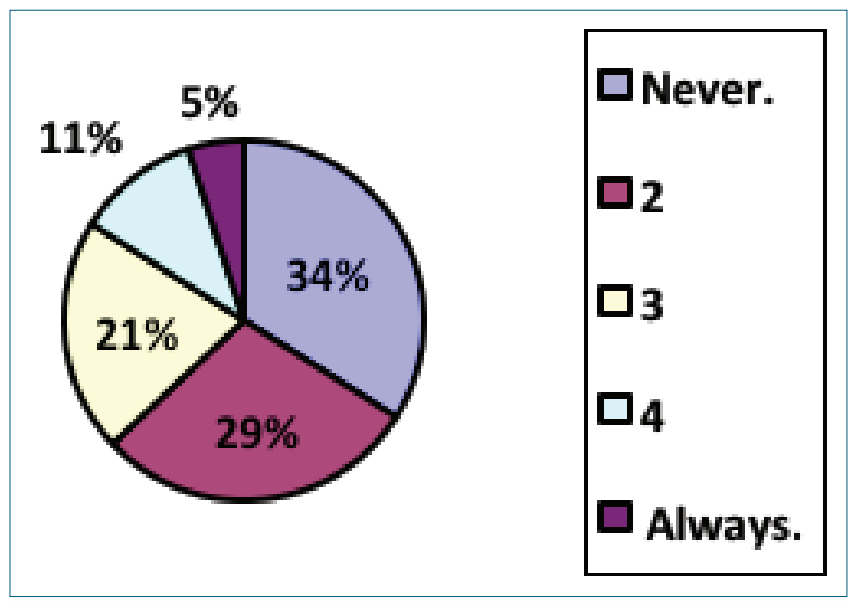

Figure 7.

Results of answers to Item 7: I study/work with people from cultural / racial / ethnical backgrounds different from mine.
Figure 7 reflects the true image of a largely mono-cultural society like the Croatian, i.e. $63 \%$ of the students never or hardly ever find themselves involved in any kind of activity with persons from different backgrounds, which is certainly a disadvantage considering the requirements of their future jobs in the maritime domain.

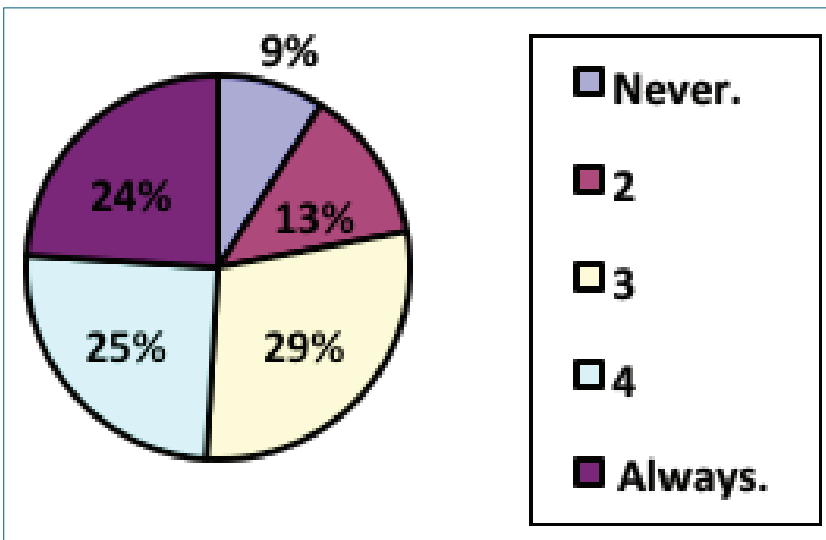

Figure 8.

Results of answers to Item 8: I go out of my way to hear/ $\mathrm{read} / \mathrm{understand}$ viewpoints other than my own.

Figure 8 shows that $9 \%$ of the students never go out of their way to understand viewpoints different from their own, while $13 \%$ of them hardly ever do so. Still, taking into consideration that $63 \%$ of the students never or have hardly ever found themselves in a multicultural setting (see Figure 7), the considerably lower number of respondents not showing open-mindedness at the beginning of their studies is already an optimistic start for the lecturer.

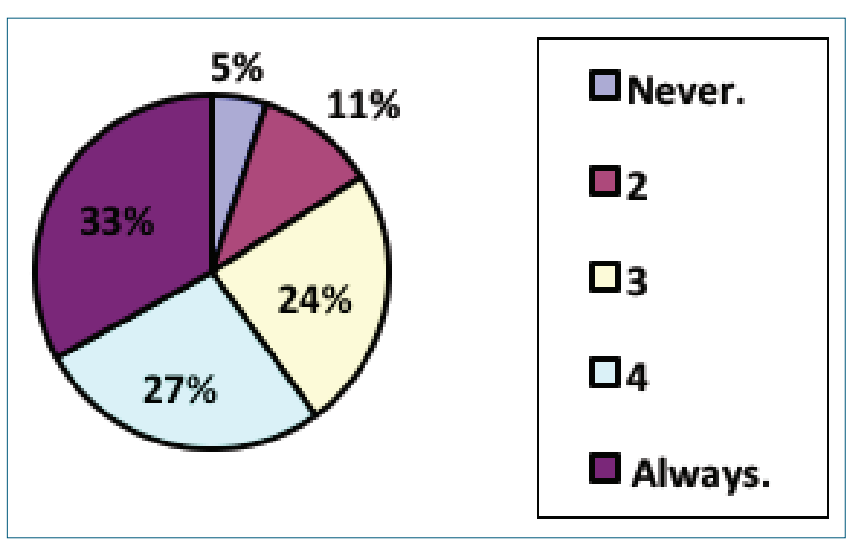

Figure 9.

Results of answers to Item 9: I try to get to know people who are different from me. 
Figure 9 shows that a still lower number of respondents, $5 \%$, have expressed refusal or reluctance to meet persons from other cultures. It is possible that a lack or an insufficient exposure to multicultural settings and situations are the main reasons for this apparent lack of interest or willingness expressed.

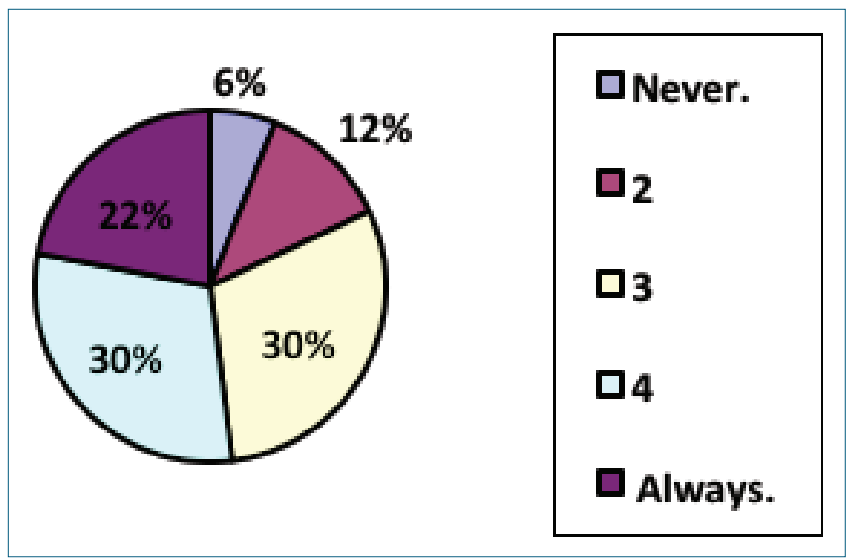

Figure 10

Results of answers to Item 10: I push myself to explore my prejudices and biases.

Figure 10 shows that still $18 \%$ of the students never $(6$ $\%)$, or hardly ever (12\%) try to recognise and analyse their own prejudices and biases. This certainly makes an important part of one's culture, i.e. of those $90 \%$ of the cultural iceberg that is not visible without a deeper immersing oneself below the surface of the conscious part of our personalities.

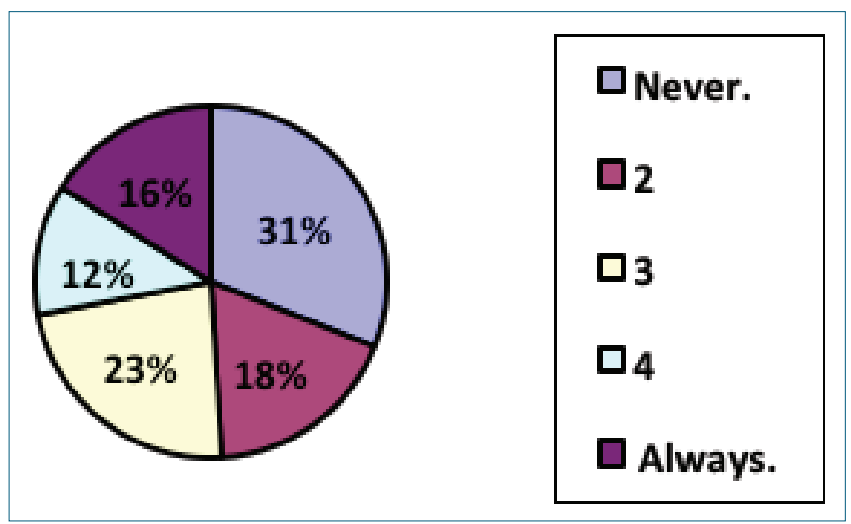

Figure 11.

Results of answers to Item 11: Discussing issues of discrimination, racism and oppression makes me uncomfortable.

Figure 11 shows that $51 \%$ of the students who answered 3,4 , or 5 , feel uncomfortable discussing 'difficult' topics such as discrimination, or oppression of any kind. Persons who intend to work in a multinational / cultural setting should be prepared to at least contemplate about such topics, which are certainly not the most pleasant ones, but university level students should already start thinking and discussing topics of interest to different social groups so as to raise their awareness of the possibilities of each individual to contribute to the empowerment of different discriminated groups.

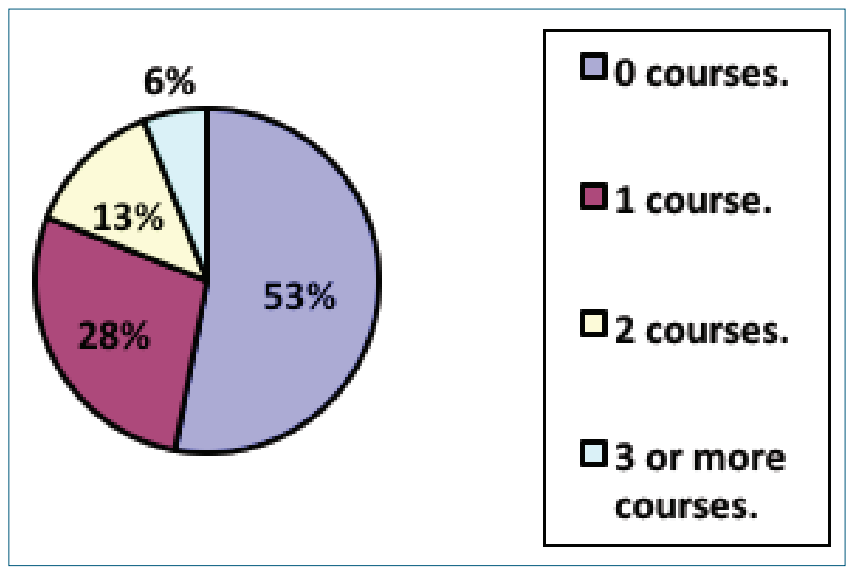

Figure 12.

Results of answers to Item 12: I have had courses/part of courses in intercultural communication.

Figure 12 shows that $53 \%$ of the students have never been exposed to any form of intentional institutional education on intercultural communication. This indicates an urgent need to include elements of cultural diversity and interaction into elementary and secondary education. This would be of particular importance for largely mono-cultural societies such as Croatian.

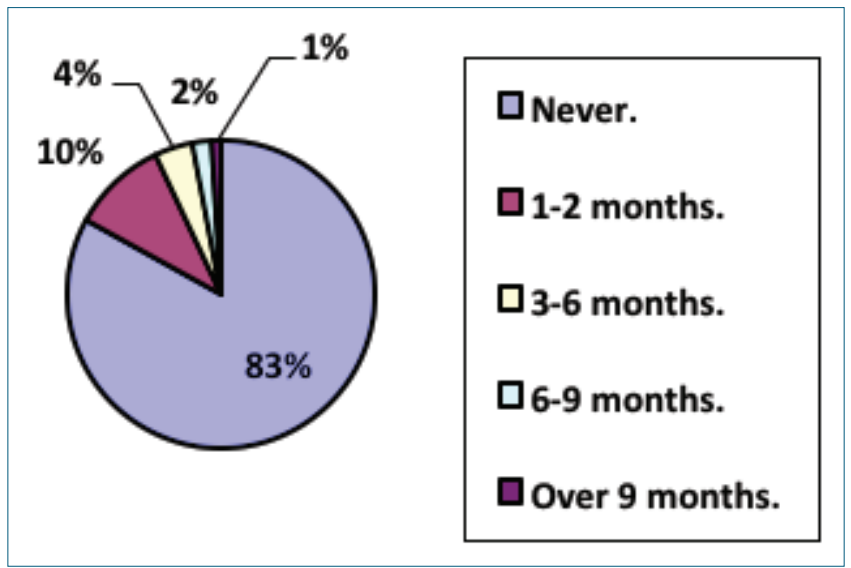

Figure 13

Results of answers to Item 13: I have lived in a contrasting community (with a very different culture from my own). 
Figure 13 further supports the thesis expressed in the analysis of the statistics presented in Figure 12. Namely, 83 $\%$ of the students have never lived in any kind of contrasting community. This indicates that their sensibility for otherness and diversity should be very low and requiring a gradual development to meet the requirements of their future jobs.

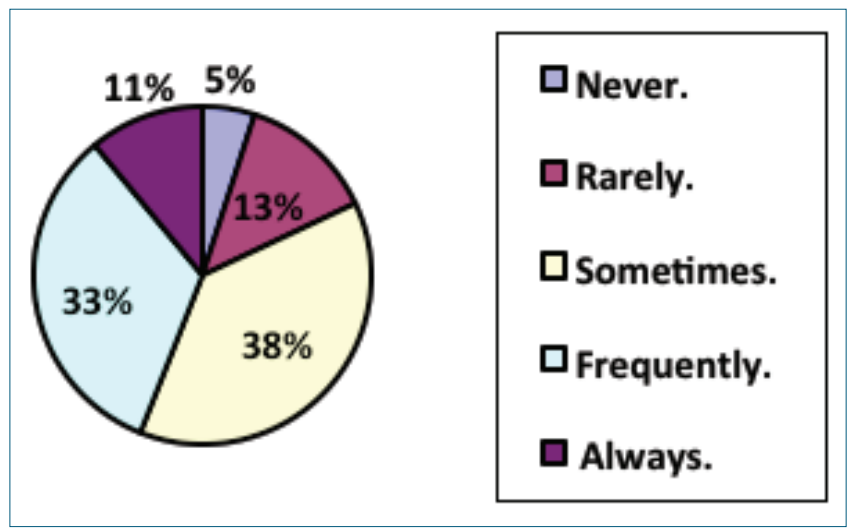

Figure 14.

Results of answers to Item 14: I pay attention to news about the world beyond my own country.

Figure 14 shows that $18 \%$ of the students never (5\%), or rarely (13\%) pay attention to the news about the world beyond their own country. Also, $38 \%$ of the students do it only sometimes, i.e. not on a regular basis, which again is an indicator of a rather low interest for otherness. Here again, a Maritime English lecturer can take the responsibility of bringing news about current events in the world to be discussed in class.

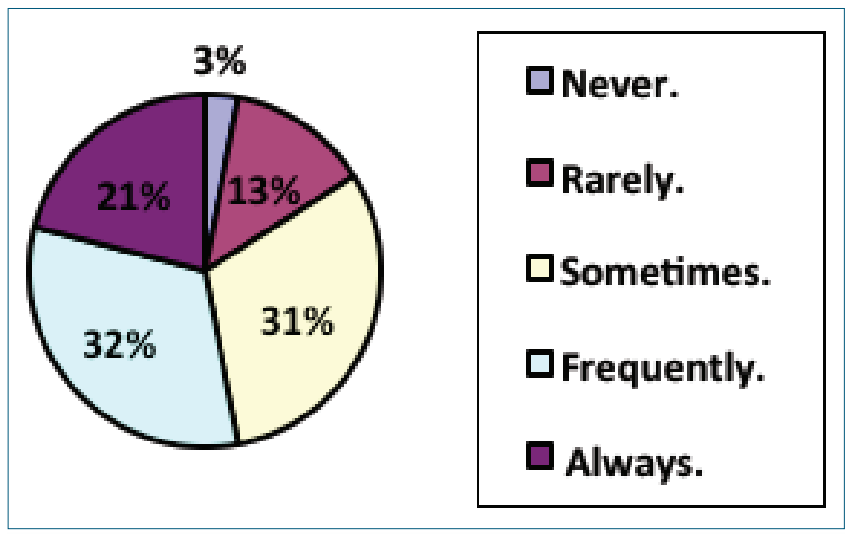

Figure 15.

Results of answers to Item 15: I enjoy media and art from different cultures.

Figure 15 shows that more than $84 \%$ of the students (answering Sometimes, Frequently, and Always) are interested in getting in touch with the media and arts from different cultures, the frequency from sometimes to regularly ranging almost evenly. Still, there are $16 \%$ of the students who never (3\%), or rarely $(13 \%)$ enjoy media or arts from cultures different from their own These are the ones to whom special attention should be paid in order to motivate them to explore other cultures and look for similarities in expressions or even diversities, which can also be attractive to foreigners.

Below, the ratio of positive $(\mathrm{P})$ to negative $(\mathrm{N})$ results of the survey is presented in Table 1 - Multicultural experience subscale, and in Table 2 - Multicultural desire subscale.

Table 1.

Multicultural experience subscale, according to survey results.

Multicultural experience subscale: average positive $71.22 \%$

\begin{tabular}{llllllllll}
\hline $\mathrm{N}$ & $6 \%$ & $24 \%$ & $16 \%$ & $32 \%$ & $37 \%$ & $53 \%$ & $83 \%$ & $5 \%$ & $3 \%$ \\
\hline $\mathrm{P}$ & $94 \%$ & $76 \%$ & $84 \%$ & $68 \%$ & $63 \%$ & $47 \%$ & $17 \%$ & $95 \%$ & $97 \%$ \\
\hline
\end{tabular}

Table 2.

Multicultural desire subscale, according to the survey results.

Multicultural desire subscale: average positive $87.66 \%$

\begin{tabular}{lllllll}
\hline $\mathrm{N}$ & $3 \%$ & $8 \%$ & $9 \%$ & $5 \%$ & $18 \%$ & $31 \%$ \\
$\mathrm{P}$ & $97 \%$ & $92 \%$ & $91 \%$ & $95 \%$ & $82 \%$ & $69 \%$
\end{tabular}


From the results presented in Tables 1 and 2, the only negative percentages on the Multicultural experience subscale refer: 1 ) to the answers to Item 12 because $53 \%$ of the students have not had any courses or parts of courses related to intercultural communication, and 2) to the answers to Item 13 because $83 \%$ of the students have never lived in a culturally contrasting community. In all the other seven items, the students' answers were predominantly positive, resulting in an average positive percentage of $71.22 \%$. As regards the Multicultural desire subscale, which has resulted from the students' answers to six items, a highly positive score over all the questions can be observed, average positive percentage of $87.66 \%$, thus allowing optimistic expectations from all the students in their future studying intercultural relations and later participating in such relations.

\subsection{Weakness of the Research Performed and Future Investigation Planned}

With all the inevitability of the research performed in order to obtain some indicators as to the suitability of the current $1^{\text {st }}$-year students - prospective seafarers or maritime affairs participants in the diversity of its sectors, the research has obvious weaknesses. This survey was carried out among the current $1^{\text {st }}$-year students, and the output results will only be available in 3 years' time, i.e. on their completing the undergraduate studies, to test their progress in multicultural sensitivity, which could indicate the need for a more systematic approach to this important issue. Therefore, on every occasion, with topic and time allowance, emphasis should be put on the multicultural aspect of a situation and on the elements indicating culture-specific behaviour, not only in the social sciences courses included in the curriculum, but also in Maritime English courses. Only then will there be a solid enough ground to investigate into the possible gain.

\section{CONCLUSION}

The investigation into the 225 FMS maritime students' multicultural experiences and desire has shown that the majority of students coming from a largely mono-cultural society, such as Croatian, are nevertheless ready to face the multicultural setting, such as a ship's crew, and also try to a certain extent to prepare themselves for the experience by opening their minds to customs and attitudes different from their own, by making friends with their peers from different cultures, by travelling to foreign countries, and by experiencing different cultures through social media. These are encouraging facts because any person aiming at working in a multicultural setting should be prepared for intercultural communication, which presupposes openness to the different by understanding, respecting, and inclusion.
In this sense, it is the task of a Maritime English lecturer to assist the students in developing their intercultural competence, not only because the English language is the communication medium in the maritime field, but also because through learning about the differences in using language functions in English as compared to their own mother tongue, the students should avoid future breakdowns in communication. This is as important for their business communication as it is important for their successful taking part in everyday personal communication in intercultural encounters with the rest of the crew.

\section{REFERENCES}

Alfiani, D.S., (2010), Multinational and multicultural seafarers and MET students: a socio-cultural study for improving maritime safety and the education of seafarers, World Maritime University Dissertations, Paper 425

Berry, J.W., (2005), Acculturation: Living successfully in two cultures, International Journal of Intercultural Relations 29(6), pp. 697-712., available at: https://doi.org/10.1016/j.ijintrel.2005.07.013

Bocanegra-Valle, A., (2015), Intercultural Learners, Intercultural Brokers and ESP Classrooms: The Case of a Shipping Business Course, Procedia - Social and Behavioral Sciences 173, pp. 106-112., available at: https://doi.org/10.1016/j.sbspro.2015.02.038

Bragg, M., (2004), The Adventure of English, UK: Sceptre.

Brodeur, A.G., (1959), The Art of Beowulf, Berkeley: University of California Press.

Crystal, D., (1995), Cambridge Encyclopaedia of the English Language, Cambridge University Press.

Crystal, D., (1997), English as a Global Language, Cambridge University Press.

Čulić-Viskota, A., (2002), Modality and Politeness, Strani jezici 32(3-4), Zagreb

Čulić-Viskota, A., (2014), Essential English for Pilotage and Tug Assistance - Proposal for SMCP Extension, Transactions on Maritime Science 3(2), pp. 158-164., available at:

https://doi.org/10.7225/toms.v03.n02.007

Čulić-Viskota, A., (2015), SMCP Development for Pilotage and Tug Assistance in the Light of Diffusion of Innovations Theory, Transactions on Maritime Science 4(2), pp. 140-150., available at: https://doi.org/10.7225/toms.v04.n02.006

Čulić-Viskota, A., Bielic, T., (2007), Cultural and Linguistic Differences as Factors of Ineffective Communication, Proceedings of IMEC-19, The International Maritime English Conference, Rotterdam, Netherlands, October 9-12.

Goffman, E., (1959), The presentation of self in everyday life, New York: Garden City. Hall, E.T., (1976), Beyond Culture, New York: Anchor Books.

Hirsch, E.D. Jr., (1987), Cultural Literacy: What Every American Needs to Know. Boston: Houghton Mifflin.

Hirsch, E.D., Kett, J. F., Trefil, J.S., (2002), The New Dictionary of Cultural Literacy (3rd ed.), Houghton Mifflin Harcourt.

History of Media, available at: http://www.encyclopedia.com/history/dictionariesthesauruses-pictures-and-press-releases/media-history

Höfstede, G., (1995), Cultures and Organizations, McGraw Hill. 
Is English Appropriate for a Global Language?, available at: http://www. thehistoryofenglish.com/issues_global.html\#Appropriate

Johnston Staver, R., (2005), A Companion to Beowulf, Greenwood Publishing Group.

Kløver, G.O., ed., (2010), Antarctic Pioneers - The Voyage of the Belgica 1897-99. Oslo: The Fram Museum.

Marlins, (2017), Diversity and Inclusion at Sea, available at: http://marlins.co.uk/ elearning/diversity-and-inclusion-at-sea/, [accessed 20 January 2017].

Narvaez, D., Endicott, L., Hill, P., (2009), Guide for Using the Multicultural Experiences Questionnaire (MEQ) For College Students and Adults, Version 3, Moral Psychology Laboratory, University of Notre Dame.

NYK Shipmanagement Itd., (2004) 1st ed., (2013) 2nd ed., Guidelines on Intercultural Relations, NYK company document (not available online).
Obraz, Hrvatski jezični portal, available at: http://hjp.znanje.hr/index. php?show=search_by_id\&id=eFtmUBE\%3D [accessed 7 March 2017].

Robbins, S. P, Coulter, M., (2005), Management 8., Pearson Prentice Hall, 2005.

Robbins, S.P., (2000), Organizational behavior: Concepts, Controversies and Applications, Prentice Hall College.

Smith, Arthur H., (1894), Chinese Characteristics, Fleming H. Revell.

Stoianovich, T., (1994), Balkan Worlds: The First and Last Europe. USA: M.E. Sharpe.

Worst Atrocities..., The Independent, available at: http://www.independent. co.uk/news/uk/home-news/worst-atrocities-british-empire-amritsar-boer-warconcentration-camp-mau-mau-a6821756.html

Zoon Politikon, available at: http://www.enciklopedija.hr/natuknica.aspx?id=67397 